\title{
Progress of SOFC/SOEC Development at DTU Energy: From Materials to Systems
}

\author{
Hagen, Anke; Hendriksen, Peter Vang
}

Published in:

E C S Transactions

Link to article, DOI:

$10.1149 / 07801.0145$ ecst

Publication date:

2017

Document Version

Peer reviewed version

Link back to DTU Orbit

Citation (APA):

Hagen, A., \& Hendriksen, P. V. (2017). Progress of SOFC/SOEC Development at DTU Energy: From Materials to Systems. E C S Transactions, 78(1), 145-153. https://doi.org/10.1149/07801.0145ecst

\section{General rights}

Copyright and moral rights for the publications made accessible in the public portal are retained by the authors and/or other copyright owners and it is a condition of accessing publications that users recognise and abide by the legal requirements associated with these rights.

- Users may download and print one copy of any publication from the public portal for the purpose of private study or research.

- You may not further distribute the material or use it for any profit-making activity or commercial gain

- You may freely distribute the URL identifying the publication in the public portal

If you believe that this document breaches copyright please contact us providing details, and we will remove access to the work immediately and investigate your claim. 


\title{
Progress of SOFC/SOEC Development at DTU Energy: From Materials to Systems
}

\author{
A. Hagen ${ }^{\mathrm{a}}$ and P. V. Hendriksen ${ }^{\mathrm{a}}$ \\ ${ }^{a}$ Department of Energy Conversion and Storage , Technical University of Denmark, \\ Frederiksborgvej 399, Roskilde, Denmark
}

DTU Energy has over the past 20 years had a very substantial effort on SOFC/SOEC development. The current project volume corresponds to $\sim 40$ man years per year. Activities span over a broad range in the value chain, from materials to cells, stacks and analyses at energy system level. In addition to that, research areas comprise ceramic processing methods, micro-structural analysis, electrochemical characterization, and modelling. Among recent highlights are electrode and cell developments, including metal supported cells, stack development durability studies under realistic operation conditions and stack operation at high pressure.

\section{Introduction}

DTU Energy is a department at the Technical University of Denmark, with currently ca. 220 employees. Research areas are energy conversion and storage technologies such as batteries, solar cells, hydrogen storage, and ceramic membranes. The largest efforts are devoted to fuel cells and electrolysis. Both high and low temperature concepts (solid oxide cells, PEM, alkaline) are pursued.

In the areas of solid oxide cells, DTU Energy has a long track record. The research has been funded from national and international sources, including collaborations with industry partners. SOFC and SOEC technologies are considered key elements in future energy scenarios in Denmark, where the political ambition is to become independent on fossil fuels by the year 2050. This goal is to be realized by increasing the shares of renewable energy sources. In 2015, more than $40 \%$ of the electricity production came from wind turbines. This number is expected to grow over the next years. In order to realize a fossil free system by 2050, and relying on electricity production primarily from wind resources, a capacity of wind turbines corresponding to $17 \mathrm{GW}$ is needed (there are 5.5 mill inhabitants in Denmark). The fluctuating character of electricity production form wind and solar demands substantial storage technologies to accommodate surplus production, efficient alternative production technologies for periods of deficiency, and load balancing. In addition, apart from the energy services, also the transport sector will need to operate on alternatives to fossil fuels. The transition to a fossil free energy system will put biomass as a carbon/hydrocarbon resource in increasing demand. However, biomass resources fall short of the demand of the energy sector, when imposing the constraint that food production comes first. Hence, in a fossil free system efficient use of biomass resources is very important.

SOCs can become a key technology to overcome these challenges. SOCs are made from relatively cheap and abundant materials. Other attractive properties of SOFCs are: high efficiencies, flexibility towards fuel gasses, i.e. hydrocarbons (biogas, natural gas, 
liquid hydrocarbons, etc.), and fair tolerance towards contaminants. Favorable SOEC characteristics are for example high efficiency, the option to work at the thermo-neutral voltage with a high current density, and the ability for $\mathrm{H}_{2} \mathrm{O}$ and $\mathrm{CO}_{2}$ electrolysis to produce synthesis gas, which can be converted to methane (even internally in the SOEC) or other storable hydrocarbons and transport fuels. In synthetic transport fuels (methane, methanol, ethanol, DME, etc.) the hydrogen to carbon ratio is higher than in biomass. Using hydrogen produced via electrolysis thus allows for an "extension" of the scarce biomass resources in the conversion of these to transport fuel. In this manner, "surplus" electricity from wind can via hydrogen obtained through electrolysis be transferred to the transport sector via biomass-derived fuels - fuels that are compatible with today's vehicles and the infrastructure in the transport sector.

The SOC research has a broad financing basis (see Figure 1). The majority of the funding has been from Danish Research programs and the remaining part from commercial projects, European projects, and internal funding.

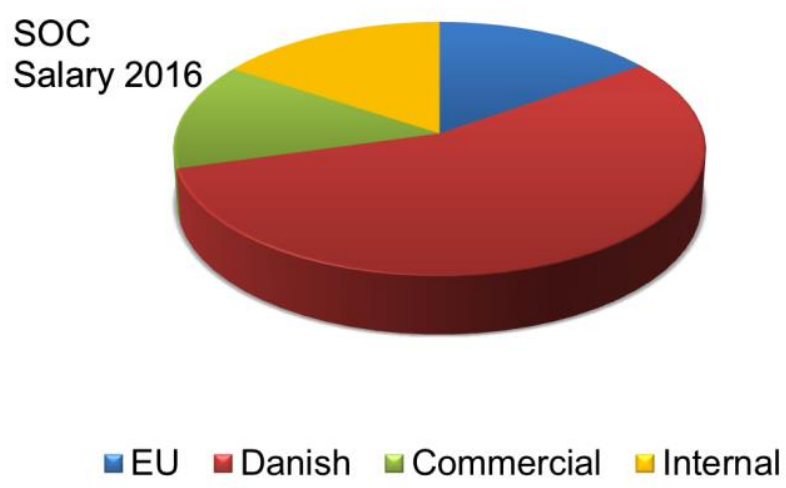

Figure 1. SOC funding in relation to manpower in 2016

\section{Recent Achievements}

\section{Electrode development}

Due to the challenges with redox stability, long term durability and "carbon tolerance" of state-of-the-art $\mathrm{Ni}$ containing SOFC anodes, alternatives have been subject of many research projects. One candidate is an oxide fuel-electrode with doped-ceria electro catalysts. The strategy for this system is illustrated in Figure 2, together with results at symmetric cell level (1).

Small and well dispersed nano particles were obtained yielding an exceptionally small electrode resistance in symmetric cell configuration. 


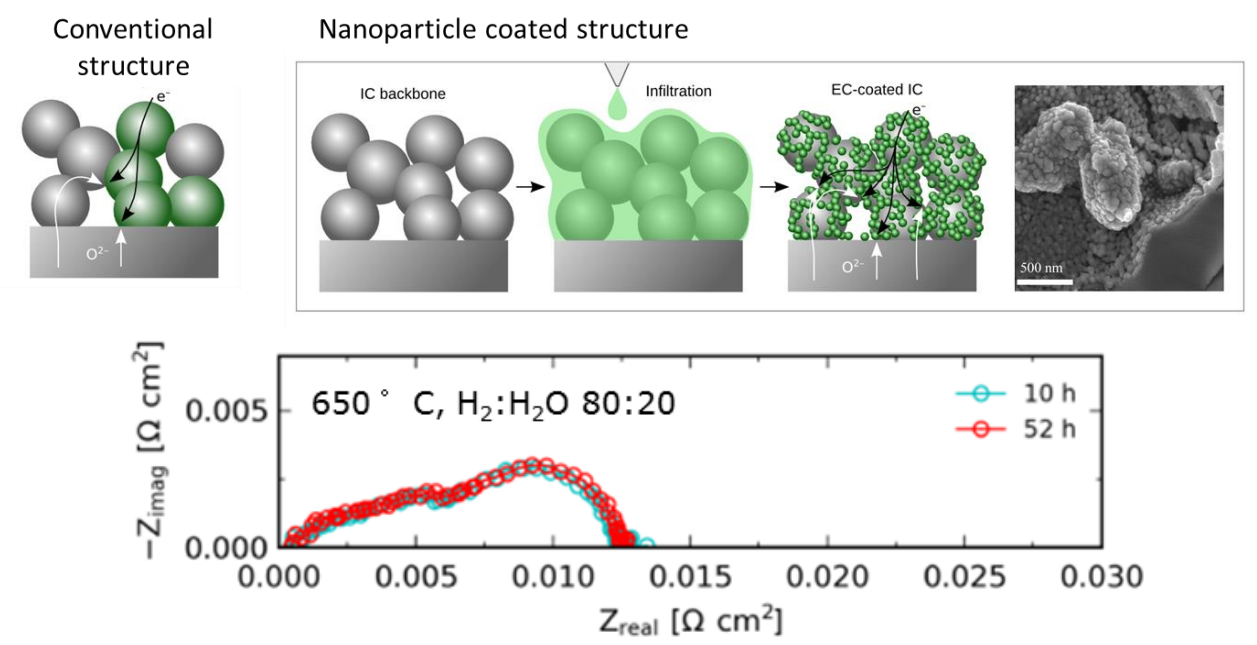

Figure 2. Concept of Ni-free anode through nano doped-ceria, EIS of a symmetric cell at $6500^{\circ} \mathrm{C}$, from ref. (1)

\section{Cell development}

Metal supported SOFC are considered promising future cell generations with high robustness and low cost. DTU Energy's concept relies on up-scalable metal supported technology including tape casting of the half cell and co-firing in reducing atmosphere, infiltration of the active anode functional layer, followed by screen printing of the cathode and in situ sintering. With the first metal supported SOFC generation, a good electrical performance and durability at $650{ }^{\circ} \mathrm{C}$ was achieved. A cell voltage degradation rate of only $0.9 \% / \mathrm{kh}$ was demonstrated over $3000 \mathrm{~h}$ (2) when operating these cells at low fuel utilization $(10 \%)$. However, when increasing the fuel utilization to more realistic values, the cells experienced severe corrosion problems and failed. A new generation was therefore developed with specific focus on increasing stability towards corrosion. This cell generation allowed for running at $70 \%$ fuel utilization without fatal corrosion failure.

The most recent developments were dedicated to a further cost reduction by decreasing the layer thicknesses and to increase the power density through micro structural optimization. In Figure 3 the performance of the most recent generation is shown (3), where the metal support thickness was reduced significantly, while the high power density from the thicker cells was maintained. 


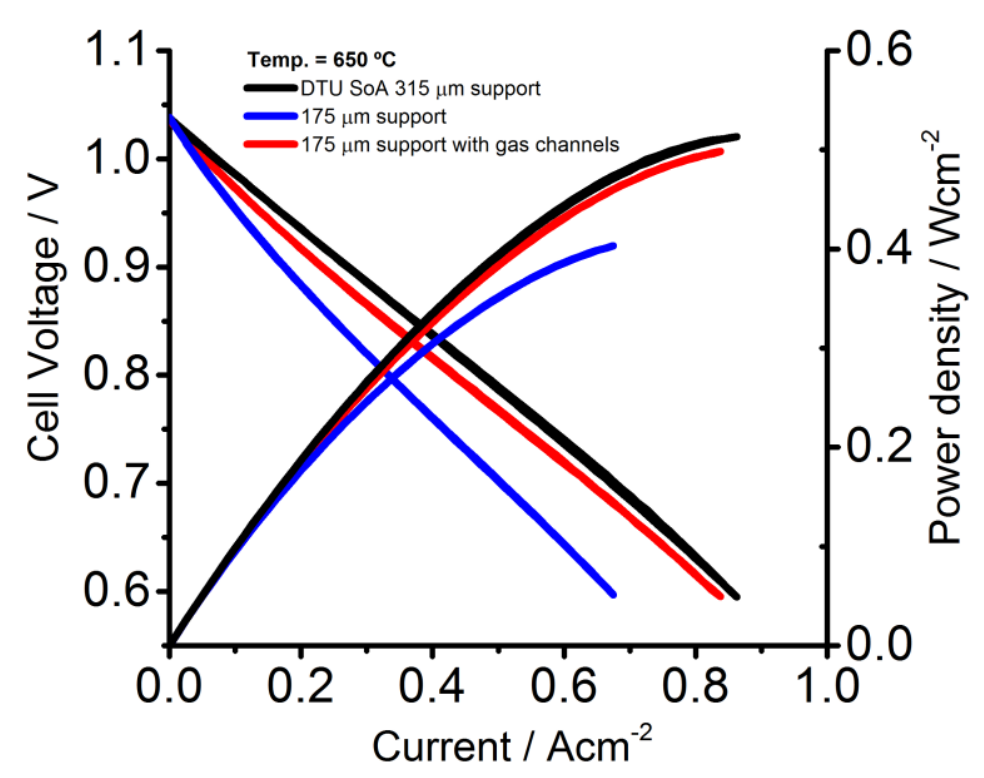

Figure 3. iV curves of three metal support cell generations at $650{ }^{\circ} \mathrm{C}$, from ref. (3)

\section{$\underline{\text { Stack development }}$}

DTU Energy has initiated the development of SOC stacks. Focus has been on a cost competitive design both through choice of materials and manufacturing processes and at the same time to ensure a long lifetime. The intention is both to minimize the degradation of the electro-chemical performance, and to improve the mechanical integrity of the stacks. The stack design was aided by modelling.

The general stack concept is presented in Figure 4.
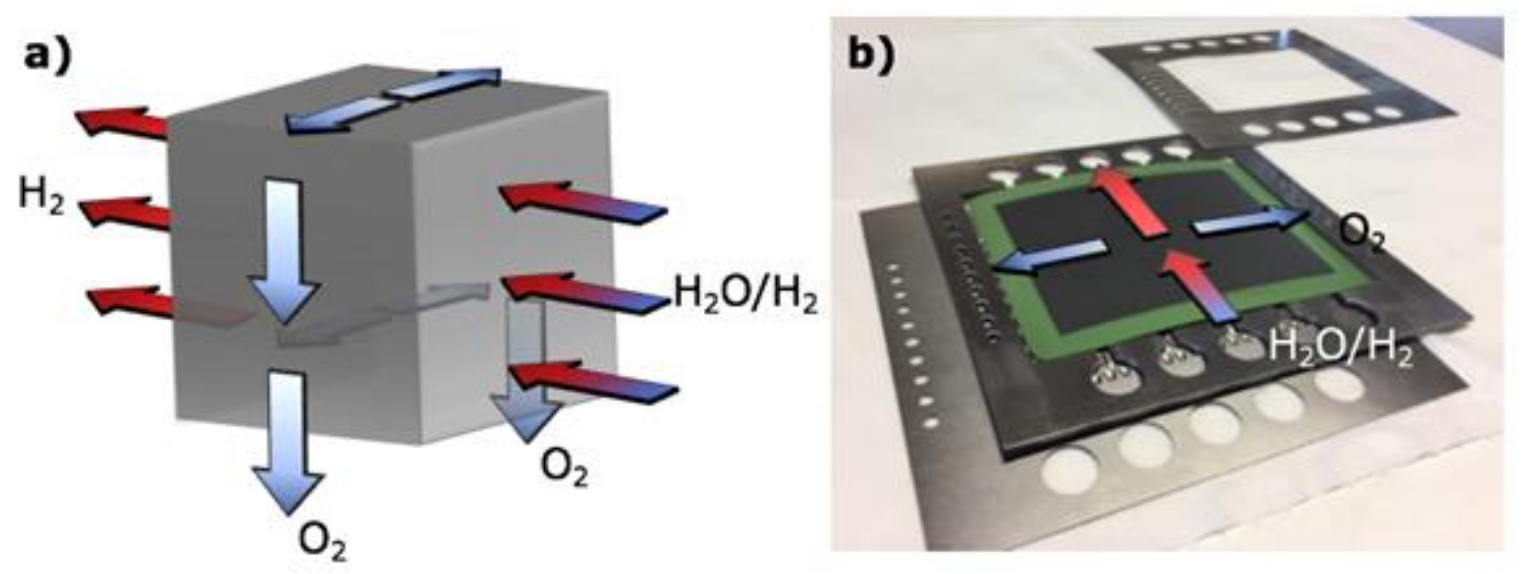

Figure 4 a) Overall flow configuration in the DTU SOEC stack, b) Flow configuration in the plane of the cell and stack components 
In the design phase, care was taken to ensure an almost linear thermal profile in the stack during operation, which is beneficial to minimize the mechanical stresses. This is true both for the stresses in the cell plane, and for the vertical stresses, which may induce loss of contact between the cell and the interconnect. To further enhance the durability of the stack with respect to this particular failure mode, flexible contact components have been introduced on either electrode. Furthermore, on the oxygen side a novel $\mathrm{Cu}-\mathrm{Mn}$ insitu reaction bonding contact layer has been utilized. This has shown to be mechanically superior to the conventional contact layers. Using these flexible contact layers also enables the use of thin seals. Thick seals usually are employed to accommodate the variations of the thickness of the layers, which naturally occurs in the production. Thinner seals are, however, an advantage to minimize the risk of mechanical failures. The use of these flexible $\mathrm{Cu}-\mathrm{Mn}$ contact layers was successfully demonstrated at single repeat unit level (4).

The development of stack technology has also included an effort on sealant materials. A high TEC glass (TEC>11.2 $10^{-6} \mathrm{~K}^{-1}$ ) has recently been developed and tested with very promising results (5). The glass contains less than $15 \%$ of silica, which is further considered an advantage as deposition of silica in the Ni/YSZ structure is a potential degradation mechanism in SOEC mode (6).

\section{$\underline{\text { Testing of SOCs }}$}

DTU Energy has extensive testing facilities that include 20 single cell test rigs, three stack test rigs, one module test rig and 3 high pressure test rigs. All rigs allow for the use of a variety of gasses and detailed electrochemical characterization such as electrical impedance spectroscopy (EIS). EIS at stack level is challenging as the magnitude of the impedance is very small (large area cells) and wiring tends to lead to an inductive coupling between the perturbation current and the voltage measurement circuit. A robust methodology has been developed (7) and very recently successfully realized also for stack tests at high pressure.

Durability of SOEC. Over the past decade, optimization has been carried out with the $\mathrm{Ni}$ /YSZ supported cell concept, by modification of the composition and microstructure of the fuel electrode and by materials selection and structuring of the oxygen electrode. The aim was to achieve commercially viable lifetimes. In Figure 6 this cell development is illustrated for two cell generations, one with LSM/YSZ oxygen electrodes, YSZ electrolyte, and Ni/YSZ fuel electrode and support (developed 10 years ago) and the other with a more recent LSC/CGO oxygen electrode, CGO barrier layer, YSZ electrolyte, and Ni/YSZ fuel electrode and support (8). 


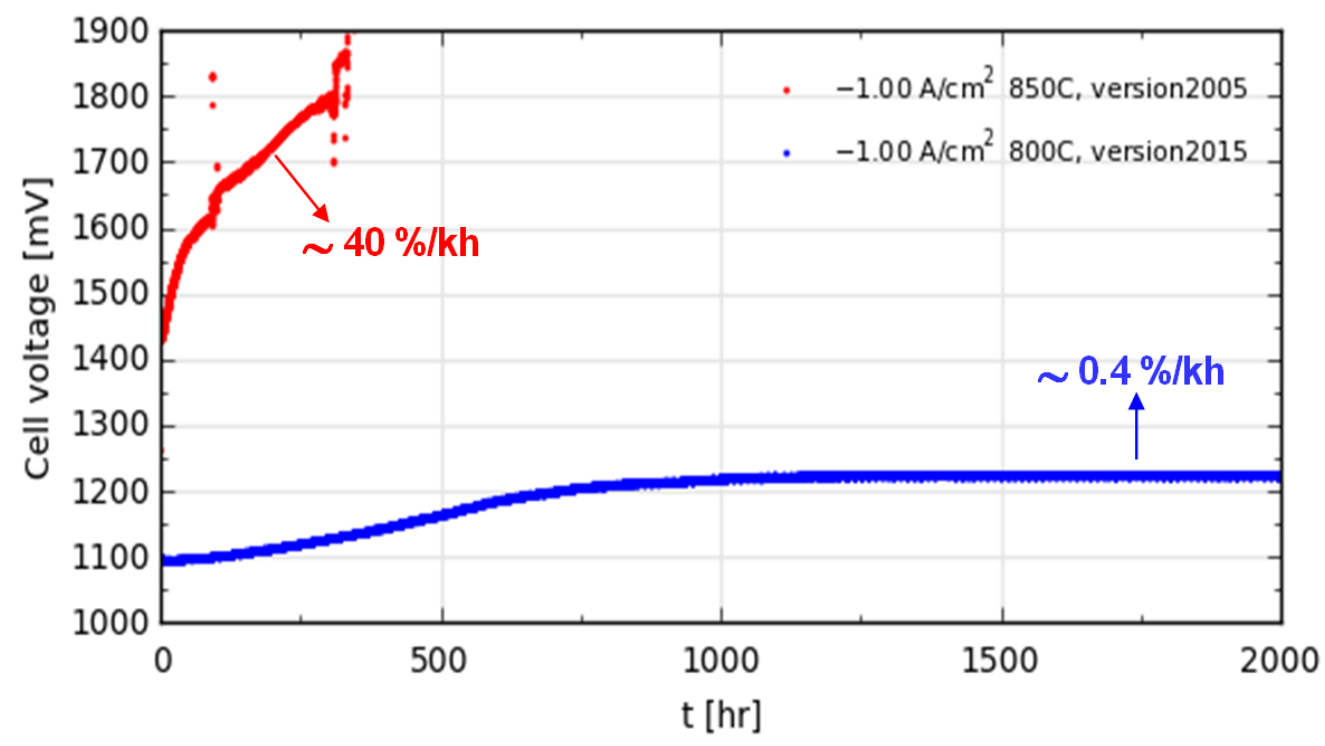

Figure 6. Cell voltage recorded over time at $-1 \mathrm{~A} / \mathrm{cm}^{2}$ at $850{ }^{\circ} \mathrm{C}$ and $800{ }^{\circ} \mathrm{C}$, red: LSM/YSZ-YSZ-Ni/YSZ, blue: LSC/CGO-CGO-YSZ-Ni/YSZ, from ref. (8)

A significant reduction of the degradation rate was achieved, from approximately $40 \% / \mathrm{kh}$ to $0.4 \% / \mathrm{kh}$. At the same time, also the initial cell performance was improved significantly, from $0.44 \Omega \mathrm{cm}^{2}$ to $0.15 \Omega \mathrm{cm}^{2}$ at $750{ }^{\circ} \mathrm{C}$, which permitted the decrease of the operating temperature.

These improvements were achieved through material and structural improvements. One major degradation mechanism at the LSM/YSZ electrode was related to micro structural deterioration at the electrolyte/oxygen electrode interface due to the high area specific resistance (ASR) of this electrode and the consequent strong polarization occurring under operation at high current density $\left(\sim 1 \mathrm{~A} / \mathrm{cm}^{2}\right)$. Use of the mixed ionic electronic conductors LSCF and LSC in the oxygen electrode instead, decreased the electrode ASR through the extension of the triple phase boundary yielding cells where not the oxygen electrode, but rather the fuel/steam electrode dominated the electrical degradation. One of the main phenomena that led to degradation of the fuel electrode was identified to be loss of Ni percolation close to the interface with the electrolyte; this can happen both in SOFC and SOEC mode $(9,10)$. The microstructural changes that may take place over very long term operation in SOEC mode $(9000 \mathrm{~h})$ in the Ni/YSZ electrode involve loss of $\mathrm{Ni}$ from the active part of the electrode and significant reduction of the effectively percolating TPB (11).

In order to avoid this degradation on the Ni/YSZ fuel electrode, significant improvements have been achieved by micro-structural optimization. More specifically, the Ni particle size was decreased from ca. $1.3 \mu \mathrm{m}$ mean diameter to $0.7 \mu \mathrm{m}$, i.e. the active surface area was increased. Further, the pore fraction was decreased from ca. $36 \%$ porosity in the active electrode layer to ca. $21 \%$ for a Ni/YSZ (8).

One of the advantages of SOEC over other low temperature electrolysis technologies is the ability to provide high current density at the thermo-neutral voltage and thereby to achieve high system efficiencies. Long-term durability tests were therefore dedicated to running at constant voltage - potentiostatic - at $1.29 \mathrm{~V}$ and $750{ }^{\circ} \mathrm{C}$. After operating two SOEC cell versions with different oxygen electrodes over $2000 \mathrm{~h}$, the final and stable 
current density was $-0.6 \mathrm{~A} / \mathrm{cm}^{2}$. Micro structural analysis revealed the Ni/YSZ electrode to be the main contributor to the degradation (12).

Harmonization of Stack Testing. DTU Energy has been actively engaged in harmonization of SOFC \& SOEC testing to pave the way for internationally comparable results and standards. In the EU SOCTESQA project, test protocols were developed for stack testing in relation to three main application areas: i) $\mu$ combined heat and power production (CHP) and auxiliary power units (APU), ii) power-to-gas SOEC, and iii) Power-to-gas-to-power reversible SOC operation. Test modules were developed including startup, initial characterization, and various application specific profiles (13). In Figure 7, the results of stack testing for selected cases are shown. Successful operation modes under constant and dynamic conditions, including thermal cycles, were demonstrated.
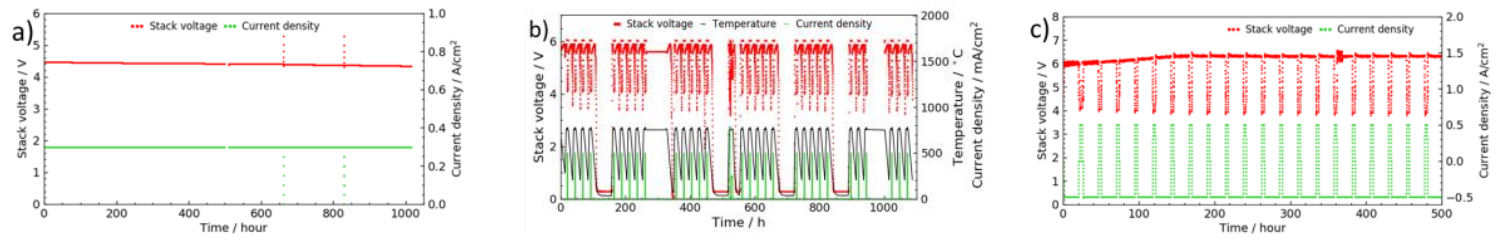

Figure 7. a) Test program for stationary SOFC application with constant operation, b) test program for mobile SOFC application, with frequent shut-down and start-up, c) Test program for Power-to-gas-to-power application (wind profile, $20 \mathrm{~h}$ SOEC, $3 \mathrm{~h}$ SOFC), all performed on SOFC stacks from the project partner Elring Klinger

Durability under realistic conditions. SOFCs are fuel flexible. That opens the valuable option to use hydrocarbon fuels. In future, fossil free energy scenarios, the use of biomass derived fuel is attractive, particularly biogas from waste (like sludge from waste water treatment or landfill sites). One of the challenges related to the use of biogas is the presence of contaminants that might poison the SOFC anode. Numerous studies have for example investigated the effect of sulphur in fuels for SOFCs and concentrations in the regions of few ppm to tens of $\mathrm{ppm}_{2} \mathrm{~S}$ seem to be tolerable in the hydrocarbon fuel. For other potential impurities, the limit might be even lower.

When considering the use of biogas as SOFC fuel, catalytic reforming reactions to form hydrogen and $\mathrm{CO}$ from the main constituent methane are the pre-steps before the electrochemical reactions. Two possible reforming concepts are steam (addition of steam to methane) and dry (addition of $\mathrm{CO}_{2}$ to methane) reforming. Dry reforming appears attractive because there are already substantial shares of $\mathrm{CO}_{2}$ in the biogas. In addition, it was found that the SOFC is less sensitive to sulphur poisoning under dry reforming conditions $(14,15)$. In recent preliminary tests it was confirmed that SOFCs can operate on real biogas from a landfill unit utilizing the dry reforming concept (see Figure 8). Even though real biogas from waste deposits is considered rich in contaminants, it was possible to operate without a cleaning unit for a certain period of time and the specific collected biogas. This is an encouraging result that points to the possibility to employ affordable gas cleaning. 


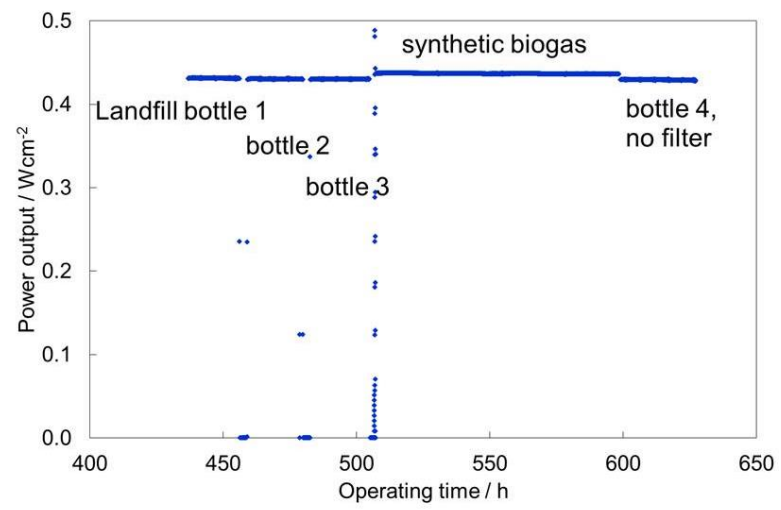

Figure 9. Power output during single cell SOFC test with real biogas from a landfill unit (bottle 1-3 with gas cleaning, bottle 4 without gas cleaning) and an intermediate period using synthetically mixed biogas under dry reforming conditions at $750{ }^{\circ} \mathrm{C}$, from ref. (15)

High pressure testing. Both, productivity and conversion efficiency can be improved if the SOC operation pressure is increased from ambient pressure to 10-30 bar. SOC operation at higher pressure with the ambition to carry out detailed electrochemical characterization such as EIS, poses complex technical challenges. At DTU Energy, high pressure rigs have been constructed and commissioned for testing single cells and stacks.

The successful operation of the high pressure stack rig was demonstrated recently. The pressure was increased to 25 bar on a 11-cell stack and DC and AC characteristics recorded. In Figure 10, iV curves and selected EIS are shown in SOFC and SOEC modes. The results confirm the decrease of the ASR with increasing pressure from 1 to $25 \mathrm{bar}$. It was further verified that high quality EIS spectra can be recorded (16).

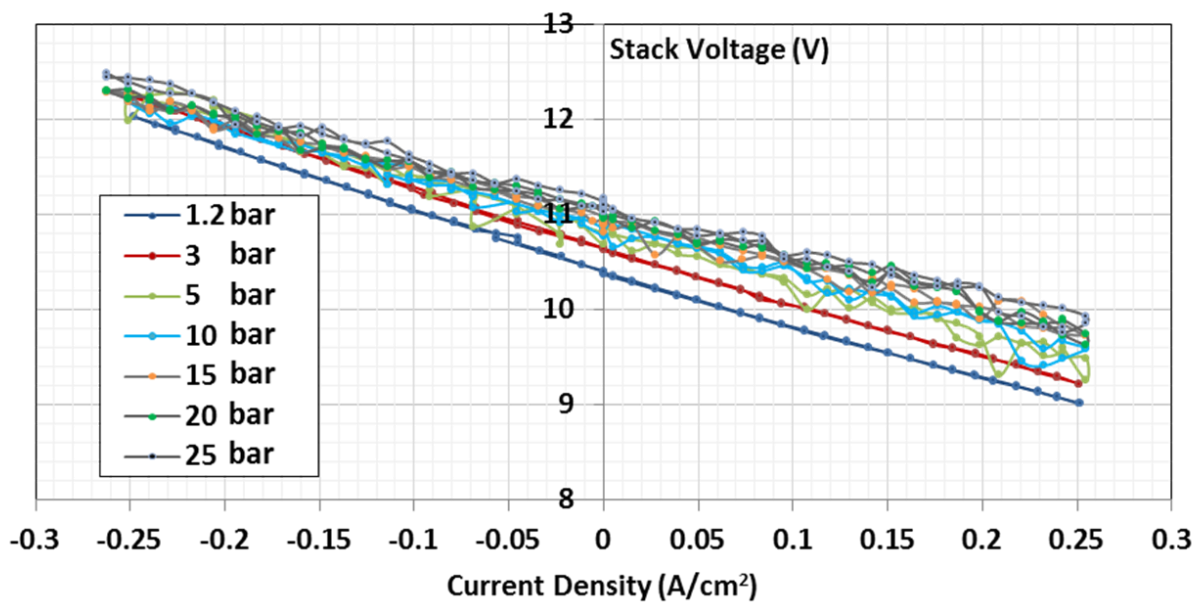



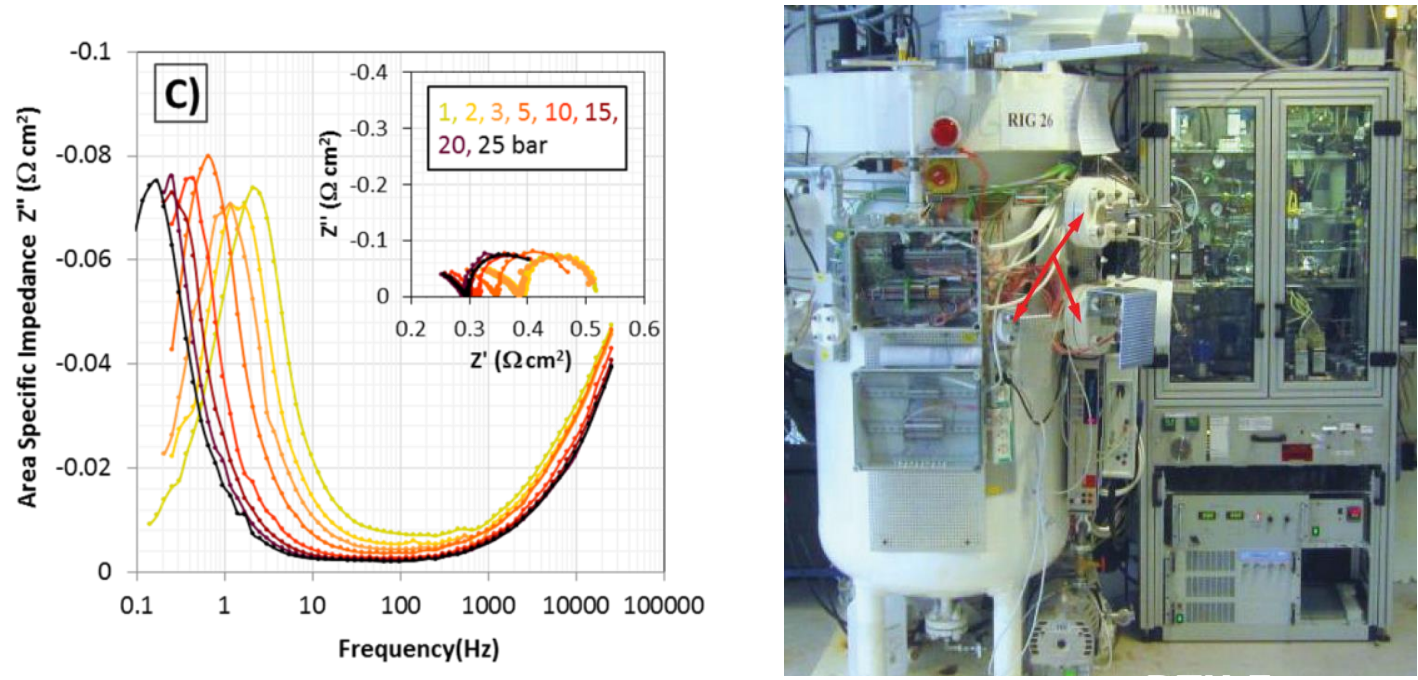

Figure 10. iV curves recorded on a 11 cell stack from Haldor Topsøe, at $750{ }^{\circ} \mathrm{C}$ using air and $50 \% \mathrm{H}_{2}+50 \% \mathrm{H}_{2} \mathrm{O}$, from ref. (16), Picture of the high pressure rig.

\section{$\underline{\text { SOFC Demonstration }}$}

DTU Energy is partner in two large European demonstration projects for micro CHP: ene.field and PACE (Pathway to a Competitive European FC mCHP Market).

EU ene.field has deployed 816 fuel cell $\mu \mathrm{CHP}$ systems in $11 \mathrm{EU}$ member states by February 2017, and aims for a total of 1051 deployed units until the end of the project in August 2017. One of the units was installed at DTU Energy (Figure 11). Among the key outcomes of the project are operational experience, performance data under real conditions, establishment of regulations, codes and standards, and evaluation of grid connection scenarios.

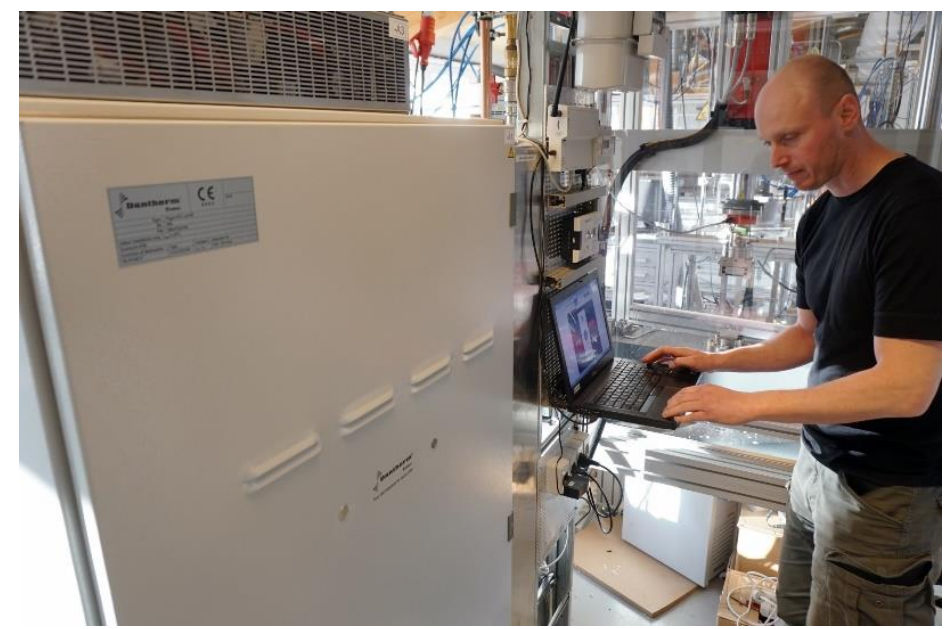

Figure 11. $\mu$ CHP unit at DTU Energy through the EU ene.field project 
The newly started EU PACE project aims at installation of more than 2,500 FC $\mu \mathrm{CHP}$ units and will thus provide the basis for further upscaling towards commercialization and also to deliver key data for further development and optimization of the fuel cell system.

Beyond participation in large European demonstration projects, DTU Energy aims at facilitating commercialization of SOFC/SOEC technology in the frame of the Test Center for Fuel Cells and Hydrogen Technologies, which offers advanced test of components, cells, and stacks education and consultancy (17).

\section{References}

1 T.L. Skafte, B.R. Sudireddy, P. Blennow and C. Graves, ECS Transactions, 72, 201 (2016).

2 B. J. McKenna, N. Christiansen, R. Schauperl, P. Prenninger, J. Nielsen, P. Blennow, T. Klemens $\varnothing$, S. Ramousse, A. Kromp, A. Weber, Fuel Cells, 13(4) 592 (2013).

3 J. Nielsen, SOFC-XV, Florida, these proceedings (2017).

4 P. Zielke, A. C. Wulff, X. Sun, S. H. Jensen, R. Kiebach, H. L. Frandsen, P. Norby and A. Hagen, Fuel Cells, submitted.

5 R. Kiebach, K. Agersted, P. Zielke, I. Ritucci, M. Brock, P. V Hendriksen, SOFCXV, Florida, these proceedings (2017).

6 A. Hauch, S. H. Jensen, J. B. Bilde-Sørensen, M. Mogensen, J. Electrochem. Soc., 154 (7), A619 (2007).

7 R. R. Mosbæk, J. Hjelm, R. Barfod, J. Høgh, P. V. Hendriksen, Fuel Cells, 13(4), 605 (2013).

8 A. Hauch, K. Brodersen, M. Chen, C. Graves, S. H. Jensen, P. S. Jørgensen, P. V. Hendriksen, M. B. Mogensen, S. Ovtar and X. Sun, ECS Transactions, 75 (42) 3 (2017).

9 A. Hagen, J.F.B. Rasmussen, K. Thydén, J. Power Sources, 196, 7271 (2011).

10 X. Sun, M. Chen, P. Hjalmarsson, Y. Liu, S. Ebbesen, S. Jensen, M. Mogensen, P. Hendriksen, J. Electrochem. Soc., 160 (9), F1074 (2013).

11 M. Trini, P. S. Jørgensen, A. Hauch, M. Chen, P. V. Hendriksen, SOFC-XV, Florida, these proceedings (2017).

12 M. Chen, X. Sun, C. Chatzichristodoulou, S. Koch, P. V. Hendriksen and M. B. Mogensen, SOFC-XV, Florida, these proceedings (2017).

13 EU Project: SOCTESQA homepage: http://www.soctesqa.eu/

14 G.B. Johnson, P. Hjalmarsson, K. Norrman, U.S. Ozkan, A.Hagen, Fuel Cells, 16(2), 219 (2016).

15 A. Hagen, A. Winiwarter, H. Langnickel, G. Johnson, Fuel Cells, submitted.

16 S. H. Jensen, X. Sun, S. D. Ebbesen and M. Chen, Fuel Cells, 16 (2), 205 (2016).

17 FCH Testcenter at DTU Energy: http://www.fch.dk/ 